Jurnal Ilmiah Pembelajaran Sekolah Dasar

Volume 1 Nomor 2 - Agustus 2019,e-ISSN 26560402

Available online at:http://ojs.uho.ac.id/index.php/jipsd

\title{
MENINGKATKAN KEMAMPUAN MEMBACA PUISI MELALUI PENERAPAN PEMBELAJARAN KONTEKSTUAL SISWA KELAS V SDN 1 LANGORI
}

\author{
Irawati $^{1)}$, Ahid Hidayat ${ }^{1)}$, La Rabani $^{1)}$, Mansyur ${ }^{1)}$ \\ ${ }^{1)}$ Jurusan Pendidikan Guru Sekolah Dasar \\ FKIP Universitas Halu Oleo \\ email: irawati.pjj@gmail.com
}

\begin{abstract}
Abstrak: Tujuan dari penelitian ini adalah untuk meningkatkan kemampuan membaca puisi siswa kelas V SDN 1 Langori Kabupaten Kolaka melalui penerapan pembelajaran kontekstual. Prosedur penelitian yaitu; (a) perencanaan (planning), (b) pelaksanaan tindakan (action), (c) observasi dan evaluasi (observation and evaluation), dan (d) refleksi (reflection). Data dalam penelitian ini terdiri dari data kualitatif dan data kuantitatif. Deskripsi kualitatif digunakan untuk menganalisis aktivitas guru dan siswa selama proses pembelajaran membaca puisi dengan pendekatan kontekstual. Deskripsi kuantitatif digunakan untuk menganalisis data peningkatan kemampuan membaca puisi siswa setelah pembelajaran dilaksanakan dalam setiap siklusnya. Hasil yang diperoleh dari penelitian ini yaitu dari kemampuan membaca puisi mengalami peningkatan yakni pada tindakan siklus I nilai ketuntasan secara klasikal adalah $45 \%$ dan nilai rata-rata siswa mencapai 65,05. Pada siklus II hasil belajar siswa untuk kemampuan membaca puisi mengalami peningkatan yakni nilai ketuntasan secara klasikal adalah $85 \%$ yang telah memenuhi Kriteria Ketuntasan Minimal (KKM) 70, dan nilai rata-rata siswa mencapai 77,85. Pada siklus I pertemuan pertama aktivitas guru mencapai 47,05\%, dan pada pertemuan kedua mencapai $58,82 \%$. Pada siklus II pertemuan pertama aktivitas guru meningkat menjadi $64,70 \%$, dan pada pertemuan kedua mencapai $94,11 \%$. Dan aktivitas belajar siswa pada siklus I pertemuan pertama mencapai $45,45 \%$ dan pertemuan kedua $54,54 \%$. Pada siklus II pertemuan pertama mencapai $72,72 \%$ dan meningkat pada pertemuan kedua mencapai 90,90\%.
\end{abstract}

\section{Kata kunci: Model Pembelajaran, Kontekstual, Hasil Belajar}

Abstract: The purpose of this research was to improve the poetry reading comprehension at the Fifth Grade students of SDN 1 Langori, Kolaka Regency through the application of contextual learning. Research procedures were (a) planning (planning), (b) implementing actions (actions), (c) observation and evaluation (observation and evaluation), and (d) reflection (reflection). The data in this research was consisted of qualitative and quantitative data. Qualitative description was used to analyze the activities of teacher and students during the learning process of reading poetry with a contextual approach. Quantitative description was used to analyze data on the improvement of the students' poetry reading comprehension after learning process was carried out in each cycle. The result of this research showed that the percentage of students' poetry reading comprehension in the first cycle was $45 \%$ and the average value of students was 65.05 . In the cycle II, students' learning outcomes for the poetry reading comprehension improved. It became $85 \%$ that already gotten the Minimum Criteria (KKM) was 70, and the average value of students in cycle II was 77.85. In the first meeting of Cycle I, teacher's activities reached $47.05 \%$, and at the second meeting reached $58.82 \%$. In the Cycle II at the first meeting, the teacher's activity improved to $64.70 \%$, and at the second meeting improved to $94.11 \%$. Then, the students' learning activities in the first meeting of Cycle I was $45.45 \%$ and in the second meeting was $54.54 \%$. In the Cycle II, at the first meeting was $72.72 \%$ and improved in the second meeting to $90.90 \%$.

Keywords: Learning Model, Contextual, Learning Outcomes 
Jurnal Ilmiah Pembelajaran Sekolah Dasar

Volume 1 Nomor 2 - Agustus 2019,e-ISSN 26560402

Available online at:http://ojs.uho.ac.id/index.php/jipsd

\section{Pendahuluan}

Dalam pengajaran bahasa Indonesia, ada empat keterampilan berbahasa yang harus dimiliki oleh siswa, yaitu keterampilan mendengarkan, berbicara, membaca, dan menulis. Budianta (2002, p.20) berpendapat bahwa sastra memiliki kegunaan sebagai media komunikasi dalam kehidupan sehari-hari, seperti penggunaan puisi untuk menyatakan perasaan cinta, marah, sedih, atau benci. Sastra melibatkan tiga komponen yaitu pengarang sebagai pengirim pesan, karya sastra sebagai pesan itu sendiri dan penerima pesan yaitu pembaca karya sastra maupun pembaca yang tersirat dalam teks atau yang dibayangkan oleh pengarang.

Pembelajaran puisi yang diajarkan di Sekolah Dasar merupakan salah satu materi pembelajaran sastra yang lebih sulit dan banyak menimbulkan masalah dibandingkan membaca karya sastra lainnya. Pembelajaran membaca puisi yang seharusnya menyenangkan ternyata membosankan dan sekaligus menakutkan, baik guru dan siswa. Pembelajaran membaca puisi adalah bagian dari pembelajaran apresiasi sastra. Pembelajaran apresiasi sastra merupakan proses antara guru dan siswa, yang menjadikan proses pengenalan, pemahaman dan penghayatan. Pada akhirnya dalam menikmati karya sastra akan mampu menerapkan di dalam kehidupan sehari-hari. Pembelajaran puisi dengan pelafalan dan intonasi yang tepat sering mengalami kendala. Kendala tersebut antara lain: (1) pengaruh dialek bahasa lokal, (2) kurang adanya percaya diri, dan (3) minimnya contoh pembacaan puisi yang benar. Kuatnya pengaruh dialek bahasa lokal, menjadikan pembacaan puisi sebagai bahan tertawaan karena terdengar lucu. Kurangnya rasa percaya diri menyebabkan siswa malu untuk maju ke depan kelas dan merasa terpaksa. Minimnya contoh membaca puisi dengan lafal dan intonasi yang tepat membuat siswa tidak memiliki acuan atau gambaran tentang membaca puisi yang tepat.

Kendala-kendala di atas menyebabkan siswa belum dapat membaca puisi dengan baik dan benar sesuai kompetensi dasar yang ditentukan. Berdasarkan hasil observasi awal, menunjukkan bahwa hasil belajar bahasa Indonesia khususnya kemampuan membaca puisi pada siswa kelas V SDN 1 Langori belum memuaskan. hasil belajar siswa kelas V khususnya pada materi pokok membaca puisi yang masih berada di bawah standar ketuntasan minimal yang ditetapkan oleh sekolah yaitu 70 (ketuntasan individu). Data hasil ulangan harian tahun pelajaran 2015/2016 siswa kelas V SDN 1 Langori menunjukkan bahwa dari 18 orang siswa, yang memperoleh nilai $\geq 70$ hanya 7 orang atau 38,9 $\%$ dengan nilai rata-rata 62,27. Oleh karena itu, salah satu upaya untuk meningkatkan kemampuan membaca puisi bagi siswa kelas V SDN 1 Langori adalah melalui penerapan pembelajaran kontekstual.

Berdasarkan uraian tersebut, penulis bermaksud menindaklanjuti dengan melakukan penelitian tindakan kelas dengan judul: "Meningkatkan Kemampuan Membaca Puisi Melalui Penerapan Pembelajaran Kontekstual Siswa kelas V SDN 1 Langori Kabupaten Kolaka".

Hasil penelitian yang dilakukan oleh Penelitian yang dilakukan oleh Bening Widiaryani (2011) berjudul "Meningkatkan Kemampuan Membaca Puisi dengan Menggunakan Pendekatan Kontekstual Pada Siswa Kelas V SD Negeri 13 Mandonga Kabupaten Kolaka Tahun Ajaran 2011/2012." Hasil penelitian diperoleh berdasarkan analisis data penilaian bahwa kemampuan membaca puisi bebas berdasarkan pengalaman siswa pada siklus I dan siklus II mengalami peningkatan. Pada siklus I nilai rata-rata membaca puisi adalah 69,5. Setelah dilakukan tindakan siklus II, nilai rata-rata meningkat menjadi 76. Dari penelitian yang dilakukan diperoleh kesimpulan bahwa dengan model pembelajaran kontekstual ternyata lebih efektif dan mampu meningkatkan kemampuan siswa kelas V SD Negeri 13 Mandonga dalam membaca puisi.

Hasil penelitian yang dilakukan oleh Leni Widya (2013) dengan judul "Meningkatkan Kemampuan Berbicara Siswa Kelas IV SD Negeri 11 Kolaka Barat dengan Menggunakan Model Pembelajaran Kontekstual". Hasil penelitian diperoleh berdasarkan analisis data penilaian bahwa kemampuan berbicara siswa dari siklus I ke siklus II mengalami peningkatan. Pada siklus I nilai ratarata siswa mencapai 67,36. Setelah dilakukan tindakan siklus II, nilai rata-rata siswa meningkat menjadi 81,18. Ini menunjukkan bahwa dengan menggunakan model pembelajaran kontekstual ternyata lebih efektif dan mampu meningkatkan kemampuan membaca siswa kelas IV SD Negeri 11 Kendari Barat. 
Model pembelajaran kontekstual dirancang secara matang dan dilaksanakan secara tepat diharapkan dapat mendorong siswa lebih dapat meningkatkan persiapan dalam menerima pelajaran. Peningkatan motivasi belajar siswa juga diharapkan membawa dampak positif yaitu peningkatan hasil belajar siswa.

Masalah dalam penelitian adalah apakah kemampuan membaca puisi siswa kelas V SDN 1 Langori Kabupaten Kolaka dapat ditingkatkan melalui penerapan pembelajaran kontekstual?. Tujuan penelitian adalah untuk meningkatkan kemampuan membaca puisi siswa kelas V SDN 1 Langori Kabupaten Kolaka melalui penerapan pembelajaran kontekstual. Penelitian ini diharapkan dapat memberikan manfaat bagi guru, siswa, sekolah dan penelitian lainnya.

\section{Metode Penelitian}

Jenis penelitian yang digunakan adalah penelitian tindakan kelas. Karakteristik yang khas dari penelitian tindakan kelas yakni adanya tindakan-tindakan tertentu untuk memperbaiki proses dan hasil belajar mengajar dikelas (Muhtar, 2002, p.27). Penelitian ini telah dilaksanakan di Kelas V SDN 1 Langori Kabupaten Kolaka pada semester ganjil tahun pelajaran 2016/2017. Subjek dalam penelitian ini adalah guru dan seluruh siswa SDN 1 Langori Kabupaten Kolaka Kelas V yang berjumlah 20 siswa. Faktor yang diteliti adalah hasil belajar, aktivitas siswa dan aktivitas guru. Penelitian tindakan kelas ini dilaksanakan dalam dua siklus yang terdiri dari empat tahapan yaitu perencanaan, pelaksanaan tindakan, observasi dan evaluasi serta refleksi. Data penelitian ini dianalisis secara deskriptif kuantitatif dan kualitatif. Deskripsi kualitatif digunakan untuk menganalisis aktivitas guru dan siswa selama proses pembelajaran membaca puisi dengan pendekatan kontekstual. Deskripsi kuantitatif digunakan untuk menganalisis data peningkatan kemampuan membaca puisi siswa setelah pembelajaran dilaksanakan dalam setiap siklusnya.

Aktivitas guru dan siswa selama proses pembelajaran membaca puisi dengan pendekatan kontekstual diamati oleh observer untuk menentukan keberhasilan proses pembelajaran berdasarkan keterlaksanaan skenario pembelajaran yang dilakukan oleh guru dan siswa dengan memperhatikan beberapa aspek yang diamati berdasarkan lembar observasi aktivitas mengajar guru dan aktivitas belajar siswa dengan kriteria sebagai berikut.

Tabel 1. Kriteria Keberhasilan Aktivitas Mengajar Guru dan Aktivitas Belajar Siswa

\begin{tabular}{|c|l|c|}
\hline No & \multicolumn{1}{|c|}{ Aspek yang dinilai } & Skor \\
\hline 1. & Langkah pembelajaran dilaksanakan & 1 \\
\hline 2. & Langkah pembelajaran tidak dilaksanakan & 0 \\
\hline
\end{tabular}

Untuk mengetahui keberhasilan pembelajaran dan kemampuan membaca puisi siswa secara individu digunakan rumus sebagai berikut:

$$
\frac{\text { Jumlah Skor Perolehan }}{\text { Jumlah Skor Maksimal }} 100
$$

Data kemampuan membaca puisi siswa akan ditelusuri melalui rata-rata perolehan siswa dalam setiap siklus, dipresentasikan, dan interprestasi peningkatan kemampuan membaca siswa dalam setiap siklus pembelajaran. Adapun untuk mengetahui kemampuan membaca secara klasikal digunakan rumus sebagai berikut:

$\%$ Klasikal $=\frac{\text { Jumlah siswa dengan Ketuntasan Individu }}{\text { Jumlah Seluruh Siswa }} \times 100$

Indikator keberhasilan penelitian ini adalah kemampuan membaca puisi siswa dan keberhasilan proses pembelajaran. Siswa dikatakan telah memiliki kemampuan membaca puisi, apabila minimal 
$80 \%$ siswa telah mendapat nilai $\geq 70$. Proses pembelajaran dikatakan berhasil jika $\geq 80 \%$ proses pembelajaran dilaksanakan sesuai dengan skenario pembelajaran.

\section{Hasil Penelitian}

\section{Hasil Belajar Siswa}

Pada siklus I presentase yang diperoleh siswa pada pertemuan pertama mencapai $45,45 \%$ dan pada pertemuan kedua mencapai 54,54\%. Pada siklus II nilai ketuntasan klasikal yang diperoleh siswa sudah mencapai $85 \%$ atau tujuh belas orang siswa yang memperoleh nilai di atas KKM atau $\geq 70$, dan masih terdapat tiga orang siswa atau 15\% yang memperoleh nilai di bawah standar ketuntasan minimal, dengan perolehan nilai rata-rata secara klasikal yang dicapai siswa adalah 77,85.

\section{Aktivitas Mengajar Guru}

Berdasarkan observasi kegiatan guru dalam proses pembelajaran pada siklus I persentase aktivitas guru berdasarkan indikator-indikator yang terdapat pada lembar observasi aktivitas mengajar guru baru mencapai $58,82 \%$. Pada siklus II pertemuan pertama mencapai $64,70 \%$ dan pada pertemuan kedua mencapai $94,11 \%$.

\section{Aktivitas Belajar Siswa}

Skor perolehan aktivitas siswa pada siklus I pertemuan pertama adalah 3 dengan persentase sebesar $60 \%$ dan pertemuan kedua adalah 4 dengan persentase sebesar $80 \%$. Skor aktivitas siswa pada siklus II adalah 5 dengan persentase sebesar $100 \%$. Pada siklus II pertemuan pertama mencapai $72,72 \%$ dan pada pertemuan kedua mencapai $90,90 \%$ dan aktivitas siswa berjalan sesuai dengan skenario pembelajaran.

\section{Pembahasan}

\section{Hasil Belajar Siswa}

Hasil belajar siswa pada siklus I meningkat pada siklus II. Pada siklus I siswa yang tidak tuntas berjumlah 11 siswa atau 55,55\% sedangkan siswa yang tuntas berjumlah 9 siswa atau 45,45\% dengan nilai rata-rata mencapai 65,05 . Dari hasil yang diperoleh menunjukan bahwa indikator kinerja pada siklus I belum mencapai target yang ingin dicapai. Sehingga, penelitian dilanjutkan pada siklus II. Dimana, pada siklus II terjadi peningkatan hasil belajar siswa. Jumlah siswa yang tidak tuntas berkurang menjadi 3 siswa atau 15\%. Adapun siswa yang tuntas berjumlah 17 siswa atau $85 \%$ dengan nilai rata-rata meningkat menjadi $77,85 \%$. Dari hasil tersebut menunjukan bahwa indikator kinerja yang ingin dicapai telah tercapai dan penelitian ini berakhir pada siklus II.

\section{Aktivitas Mengajar Guru}

Hasil observasi aktivitas mengajar guru pada siklus I menunjukan bahwa keberhasilan aktivitas mengajar guru pada pertemuan pertama adalah 47,05\% dan pertemuan kedua 58,82\%. Dari hasil tersebut menunjukan belum mencapai indikator kinerja $80 \%$. Sehingga, guru harus lebih aktif dalam proses pembelajaran pada siklus berikutnya dan melihat kekurangan yang terjadi pada siklus I. Pada hasil observasi aktivitas mengajar guru di siklus II menunjukan peningkatan. Persentase keberhasilan aktivitas mengajar guru pada pertemuan pertama adalah 64,70\% dan pertemuan kedua mencapai $94,11 \%$. Hasil tersebut sudah mencapai indikator kinerja yang ditetapkan yaitu minimal $80 \%$ aktivitas guru telah terlaksana dengan baik dan pertemuan berakhir di siklus II. 
3. Aktivitas Belajar Siswa

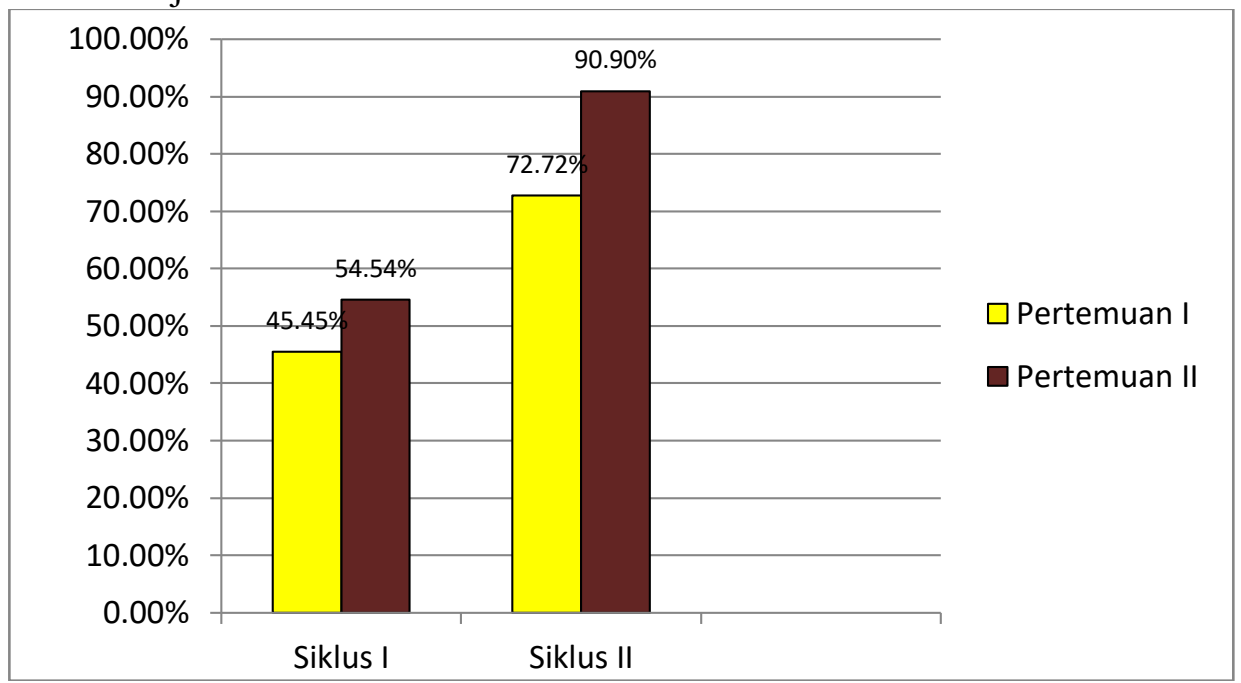

Gambar 1. Persentase Aktivitas Belajar Siswa

Berdasarkan gambar 1 dapat terlihat bahwa kurangnya perhatian siswa terhadap penjelasan guru dalam proses pembelajaran berpengaruh pada persentase keberhasilan aktivitas belajar siswa.seperti pada persentase keberhasilan aktivitas siklus I pertemuan pertama 45,45\% dan pertemuan kedua 54,54\%. Melihat kekurangan yang masih ada serta hasil belajar siswa belum mencapai indikator $80 \%$, maka penelitian dilanjutkan di siklus II sesuai dengan perencanaan tindakan. Hal-hal yang harus diperbaiki pada siklus II, guru lebih memotivasi siswa untuk mengikuti pelajaran dan mengolah tahapan kegiatan pembelajaran dengan baik berdasarkan skenario pembelajaran dengan menggunakan model pembelajaran kontekstual. Hasil observasi keberhasilan aktivitas belajar siswa pada siklus II mengalami peningkatan dimana pada pertemuan pertama adalah $72,72 \%$ dan pada pertemuan kedua adalah $90,90 \%$. Sehingga, mencapai indikator kinerja yang diharapkan yaitu $80 \%$ aktivitas belajar siswa telah terlaksana dengan baik.

Varita (2010, p.4) mengemukakan bahwa 'Comprehension is an important aspect of reading. Reading comprehension is basically the essence of the reading process. Tarigan (2008, p.7) mengemukakan bahwa 'Comprehension is an important aspect of reading. Reading comprehension is basically the essence of the reading process. Reading is an important skill to master by every individual. According to Tarigan, reading is a process which is done and used by the reader to get a message which is delivered by the writer through written language'.

Suryawati \& Osman (2017, p.5) mengemukakan bahwa 'Stages in the construction of contextual learning module consist of Working Plans, Teaching Preparation and Teaching Modules.' Pembelajaran kontekstual dapat dikatakan sebagai sebuah pendekatan pembelajaran yang mengakui dan menunjukkan kondisi alamiah dari pengetahuan. Melalui hubungan di dalam dan di luar kelas, suatu pendekatan pembelajaran kontekstual menjadikan pengalaman lebih relevan dan berarti bagi siswadalam membangun pengetahuan yang akan mereka terapkan dalam pembelajaran seumur hidup. Pembelajaran kontekstual menyajikan suatu konsep yang mengaitkan materi pelajaran yang dipelajari 
siswa dengan konteks dimana materi tersebut digunakan,serta berhubungan dengan bagaimana seseorang belajar atau gaya siswa belajar (Trianto, 2011, p.104).

\section{Simpulan}

1. Penerapan pembelajaran kontekstual dalam pembelajaran Bahasa Indonesia pada materi membaca puisi pada kelas V 1 Langori dapat meningkatkan kemampuan membaca puisi siswa. Nilai rata-rata siklus I mencapai 65,05 dengan persentase ketuntasan secara klasikal mencapai 45\%. Pada siklus II nilai rata-rata meningkat menjadi 77,85 dengan persentase ketuntasan secara klasikal $85 \%$.

2. Penggunaan pendekatan pembelajaran kontekstual pada pada kelas V 1 Langori telah berhasil diterapkan di dalam kelas terlihat pada aktivitas mengajar guru dengan menggunakan pendekatan pembelajaran kontekstual, pada tindakan siklus I pertemuan pertama mencapai $47,05 \%$ dan pertemuan kedua mencapai $58,82 \%$. Pada tindakan siklus II pertemuan pertama mencapai $64,70 \%$ dan pertemuan kedua mencapai $94,11 \%$.

3. Penggunaan model pembelajaran kontekstual dapat meningkatkan aktivitas belajar siswa. Dilihat pada tindakan siklus I pertemuan pertama aktivitas belajar siswa mencapai $45,45 \%$ dan pertemuan kedua mencapai $54,54 \%$. Pada tindakan siklus II aktivitas belajar siswa meningkat pada pertemuan pertama mencapai $72,72 \%$ dan pertemuan kedua mencapai $94,11 \%$.

\section{Daftar Pustaka}

Budianta, Melani. 2002. Membaca Sastra. Depok Indonesia.

Muhtar, Roni. 2002. Penelitian Tindakan Kelas bagi Guru. Kolaka: FKIP Unhalu.

Suryawati, Evi \& Osman, Kamisah 2017. Contextual Learning: Innovative Approach towards the Development of Students' Scientific Attitude and Natural Science Performance. EURASIA Journal of Mathematics, Science and Technology Education. https://doi.org/10.12973/ejmste/79329

Tarigan, HG. 2008. Membaca Sebagai Suatu Keterampilan Berbahasa. Bandung: Angkasa.

Trianto. 2011. Model-Model Pembelajaran Inovatif Berorientasi Konstruktifistik. Konsep, Landasan Teoretis-Praktis dan Implementasinya. Jakarta: Prestasi Pustaka Publisher.

Varita, Detty. 2010. Improving Reading Comprehension Through Literature Circles. Syiah Kuala University, Banda Aceh. www.jurnal.unsyiah.ac.id > article > download.

Widiaryani, Bening. 2011. "Meningkatkan Kemampuan Membaca Puisi dengan Menggunakan Pendekatan Kontekstual pada Siswa Kelas V SD Negeri 13 Mandonga Kabupaten Kolaka Tahun Ajaran 2011/2012”. Skripsi Universitas Haluoleo.

Widya, Leni. 2013. "Meningkatkan Kemampuan Berbicara Siswa Kelas IV SD Negeri 11Kolaka Barat dengan Menggunakan Model Pembelajaran Kontekstual”. Skripsi Universitas Haluoleo. 